\title{
Nuclear and Cell Divisions in Zoospore Formation of Ulva pertusa Kjellman
}

\author{
by Hiroshi YABU* and Jun ToKIDA*
}

Received October 9, 1959

Cytological studies of the green algae belonging to the family Ulvaceae have been reported to date by four investigators, viz., $\left.\left.\operatorname{Carter}^{1}\right), \mathrm{F} \phi \mathrm{yn}^{2}, 3\right)$, Ramanathan $^{4}$ ), and Niizeki $\left.{ }^{5}\right)$. Meiosis in those algae has been established to take place in zoospore formation by $\mathrm{F} \phi \mathrm{yn}^{3}$ ) and Ramanathan ${ }^{4}$.

Among the Japanese species of this family, Enteromorpha Linza (L.) J. Ag. is the only one that has hitherto been treated cytologically ${ }^{5}$ ). In the present paper, the writers wish to report some results of their recent investigation on the nuclear and cell divisions in zoospore formation of Ulva pertusa Kjellm.

The material was collected in the middle of April, 1955 at Nanaehama near Hakodate. It was brought to the laboratory and kept alive for some time in glass vessels containing sea-water. The fixation of the material was done from $8 \mathrm{p} . \mathrm{m}$. of the collection day to $6 \mathrm{a} . \mathrm{m}$. of the following day at intervals of 30 minutes, with two kinds of fixing fluids, viz., Navashin's solution and Flemming's weaker solution made up, of course, with sea-water. Three to four hours were sufficient for fixing. Sections were cut $2-3 \mu$ in thickness by the paraffin method at right angles or parallel to the surface of the thallus, and were stained with Heidenhain's iron haematoxylin. In a section cut parallel to the thallus surface, the nuclei were likely to be confused with the pyrenoids, so the observation here described was made with the sections cut at right angles to the thallus surface.

Thallus cells adjacent to the fertile area of the zoospore-producing material always contained a single nucleus near the center of the cell cavity and a single nucleolus within each nucleus. In the beginning of the nuclear division, the nucleus and the nucleolus gradually increased in size. Thin chromatin threads soon appeared in the nuclear cavity and the synapsis stage set in. Then the threads spread to fill up the whole cavity (Fig. 5). In diakinesis stage, a few V-shaped chromosomes were observed (Fig. 6). Thirteen bivalent chromosomes were counted in this and the following stages (Figs. 6-8). This haploid chromosome number coincides with that counted by $\left.\mathrm{F} \phi \mathrm{yn}^{3}\right)$ in Ulva lactuca, but not with those reported by Carter ${ }^{1}$ ) in Ulva lactuca and by Ramanathan ${ }^{4}$ ) in Enteromorpha compressa var. ligulata. It also differs from the chromosome number reported recently by $\mathrm{Niizeki}^{5}$ ) in his materials of Enteromorpha Linza collected in Tokyo Bay. He reports that his materials were considered to be a strain represented by haploid generation only, and that they produced biflagellate asexual swarmers without meiosis and 12 chromosomes were counted at metaphase of the first nuclear division in the swarmer formation.

The nucleolus and the nuclear membrane disappeared completely in metaphase and reappeared in telophase (Fig. 11). In side view of the metaphase, a small centrosomelike body was clearly observed at each pole of the spindle (Figs. 9 and 22). Equatorial plate of the first nuclear division was always parallel to the thallus surface, therefore the cell division following the first nuclear division was likewise parallel to the thallus surface. In the daughter cells thus formed, the second nuclear division started

* Phycological Laboratory, Faculty of Fisheries, Hokkaido University, Hakodate, Japan. 

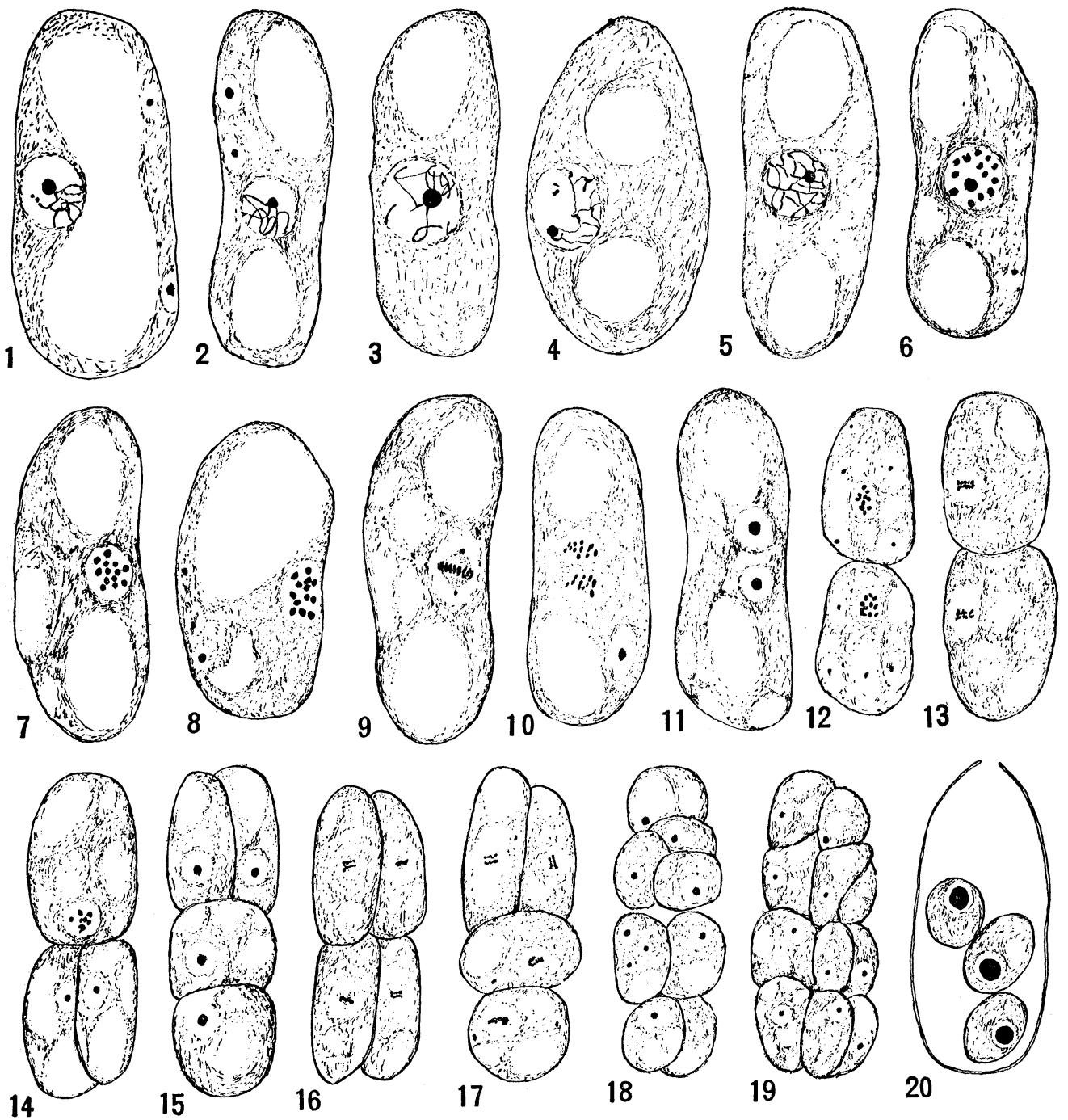

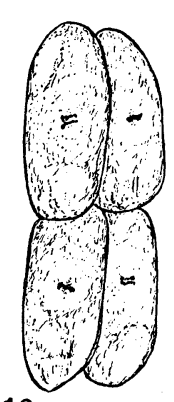

16

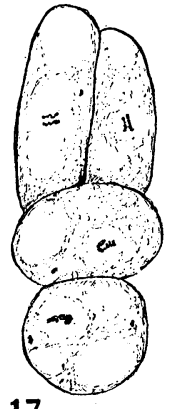

17

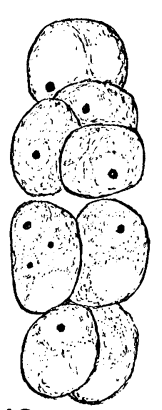

18

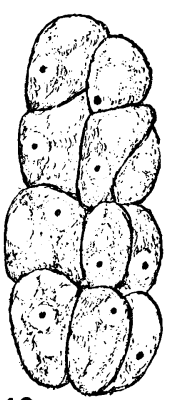

19

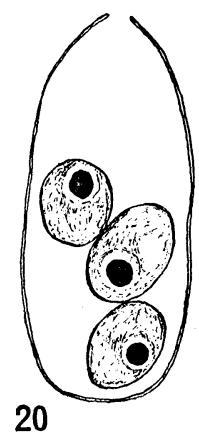

Figs. 1-20. Nuclear and cell divisions in fertile cells of the sporophyte of Ulva pertusa: 1-4, synapsis; 5 , spireme; 6 , diakinesis; 7-8, late prophase; 9 , metaphase; 10 , anaphase; 11 , interkinesis; $12-15$, the second nuclear division; 12, late prophase; 13 , metaphase; 14, three-cell stage; 15, four-cell stage; 16-17, metaphase of the third nuclear division; 18, eight-cell stage; 19 , sixteen-cell stage; 20 , zoosporangium after the liberation of zoospores, three of which still remain within. (Figs. $1-20, \times 1870$ )

immediately (Figs. 12 and 13). The second cell division was either at a right angle or parallel to the thallus surface (Figs. 14-17). The second and the succeeding nuclear divisions in all of the cells produced in a young zoosporangium generally took place simultaneously (Figs. 12, 13, 16 and 17), but sometimes with a slight discrepancy as shown in Fig. 14. As a result of the successive third and fourth nuclear and cell divisions, 16 small cells were eventually formed within a zoosporangium, and each of those small cells was converted into a quadriflagellate zoospore (Fig. 20). As for the number of the zoospores formed in each sporangium, Printz $z^{6}$ gives " $4-8$ " in his 


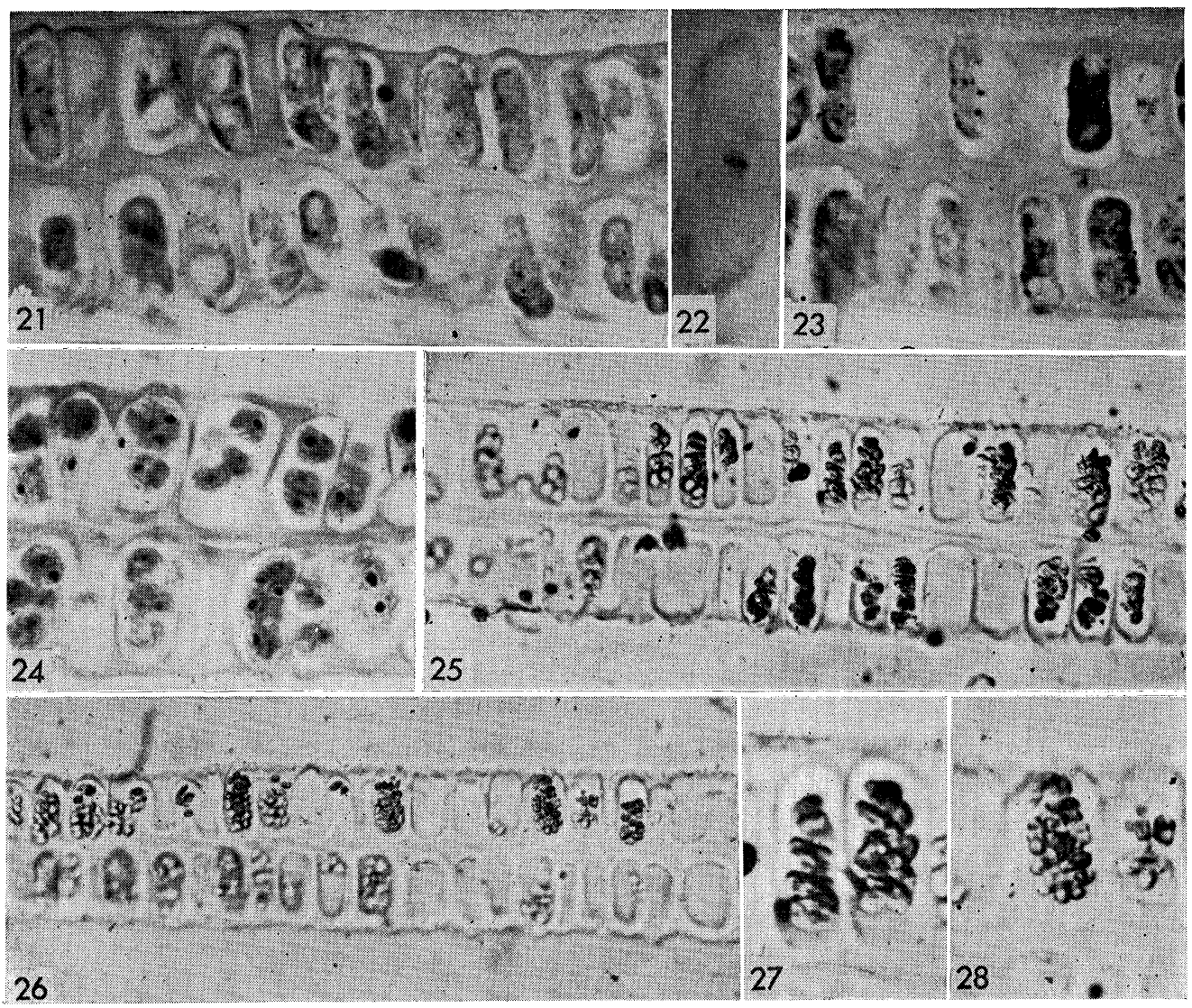

Figs. 21-25 and 27. Photomicrographs of microtome sections through fertile parts of the sporophyte of Ulva pertusa: 21, part of a section showing cells at the stages of the first and second nuclear divisions; 22, a single cell showing side view of the metaphase of the first nuclear division; 23, part of a section showing cells mostly at the stages of the second and third nuclear divisions; 24, part of a section showing mature zoosporangia; 25, part of a section stained with aniline blue showing mature zoosporangia containing 16 zoospores; 27, part of Fig. 25, enlarged. (Figs. 21, 23 and 24, $\times 680$; Fig. 22, $\times 1400$; Fig. 25, $\times 425$ )

Figs. 26 and 28. Photomicrograph of a microtome section, stained with aniline blue, through a fertile part of a gametophyte of Ulva pertusa, showing mature gametangia containing 32 gametes; 28, part of the preceding figure, enlarged. (Fig. 26, $\times 425$; Fig. 28, $\times 850$ ).

general account of the family Ulvaceae. However, the writers have ascertained that Ulva pertusa collected at Nanaehama produced 16 zoospores in each sporangium (Figs. 19 and 25). By the way, the number of gametes produced in each gametangium of this species was 32 in the writer's specimens from Nanaehama (Fig. 26), while it was described by Print $z^{6}$ ) in Ulvaceae as " 8 (seltener 4 oder 16)."

\section{Summary}

The zoosporophyte of Ulva pertusa Kjellm. collected near Hakodate is reported here to have been proved cytologically to undergo meiosis in zoospore formation as previous authors have already reported in other species of Ulva and Enteromorpha. Haploid chromosome number was established to be 13 . A centrosome-like body was 
present at each pole of the spindle in the metaphase of meiosis. Each sporangium produced 16 quadriflagellate zoospores.

The present study was supported in part by a grant in aid for Miscellaneous Scientific Research from the Ministry of Education.

\section{References}

1) Carter, N., Ann. Bot. 40: 665 (1926). 2) F $\phi y n$, N., Ber. Deutsch. Bot. Ges. 47: 495 (1929). 3) —- Arch. f. Protistenk. 83: 154 (1934). 4) Ramanathan, K. R., Ann. Bot. N. S. 3: 375 (1939). 5) Niizeki, S., Nat. Sci. Rept. Ochanomizu Univ. 8: 45 (1957). 6) Printz, H., "Chlorophyceae" in A. Engler, Natürl. Pflanzenfam. 2. Aufl. 3 Bd. 463 pp. Leipzig (1927).

$$
\begin{aligned}
& \text { 摘要 } \\
& \text { アナアオサの游走子形成の際の核拉よび細胞分裂 }
\end{aligned}
$$

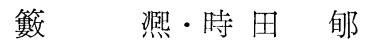

函館付近で採集したアナアオサの胞子体は細胞学的にしらべた結果，アオサ属とアオノリ属の外国種で すでに報告されているところと一致して，游走子形成の際に減数分裂を行ならことをたしかめた．染色体 数は $n=13$ であった．核分裂中期の側面観で紡錪体の両極に中心体が明らかに見られた．核扮よび細胞の 分裂は 4 回つづけて行なわれ，游走子囊内には結局 16 個の游走子が形成される. 游走子は鞭毛 4 本を有

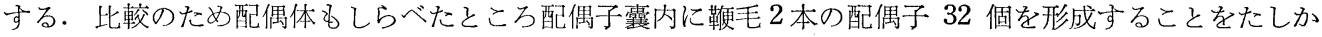
めた。緑藻アオサ科の日本産の種類で減数分裂を観察した報告は今日まで他に知られていない。(北海道大 学水産学部水産植物学教室) 